\title{
La Vignetta
}

di Giulia Ferrandi

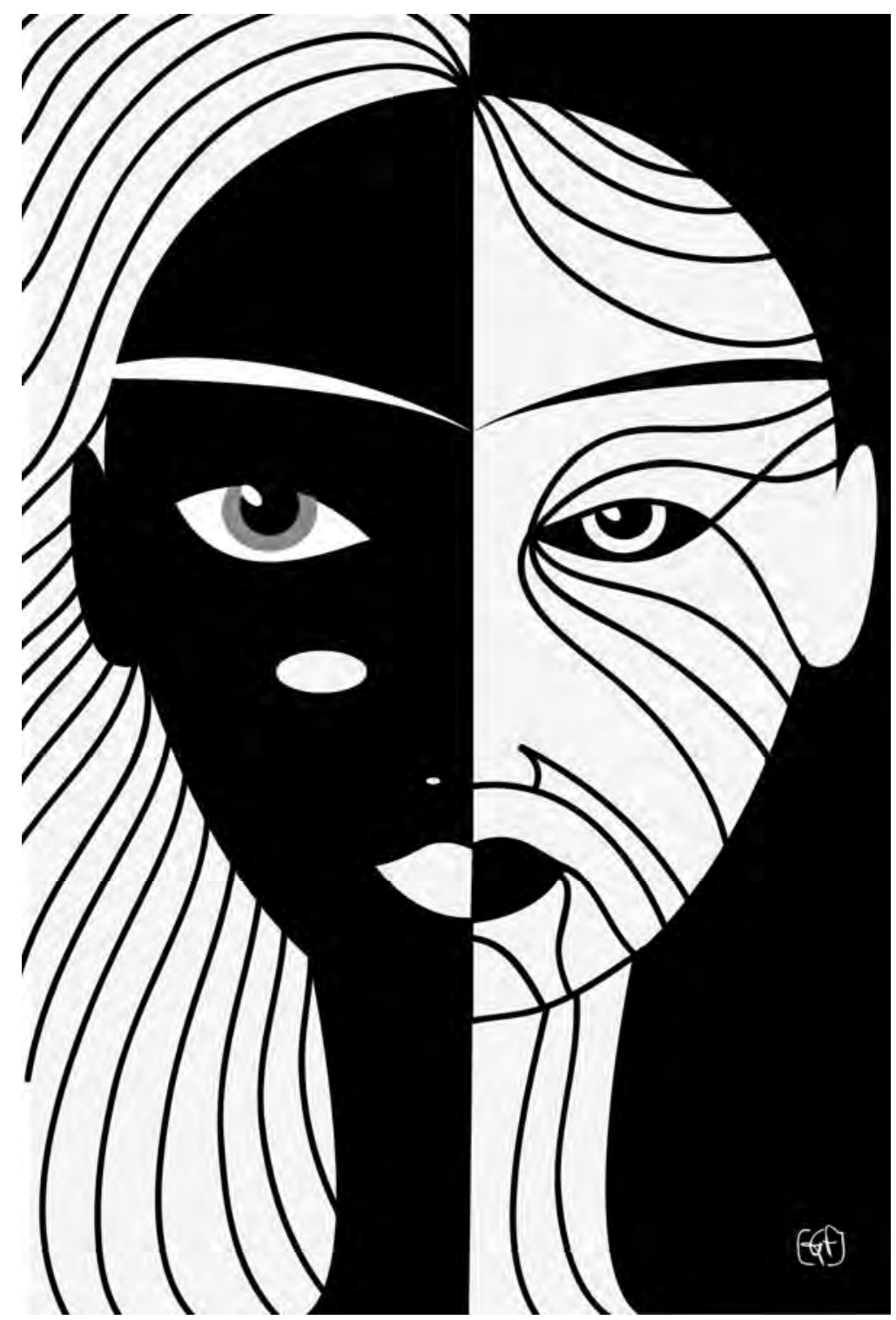

Prisma Economia Società Lavoro, anno VI, n. 3, 2015

Copyright (C) FrancoAngeli

N.B: Copia ad uso personale. È vietata la riproduzione (totale o parziale) dell'opera con qualsiasi mezzo effettuata e la sua messa a disposizione di terzi, sia in forma gratuita sia a pagamento. 